\title{
Cosmetic Translation Competence - A Theoretical Model and Implications for Translator Training
}

\author{
Kompetencja tłumaczeniowa w przekładzie kosmetycznym \\ - model teoretyczny oraz implikacje dla translodydaktyki
}

\author{
Beata PIECYCHNA ${ }^{1}$
}

Uniwersytet w Białymstoku

\begin{abstract}
In the last decade, cosmetic translation has become increasingly significant as the beauty and cosmetic industry has grown exponentially across the globe. The expansion of international cosmetic brands in many countries around the world necessitates commissioning competent, well-prepared translators, who are able to handle translation problems typical of various types of cosmetic translation, both specialized and those requiring skills specific to a more creative rendition. The main objective of this paper is to discuss a novel theoretical model of cosmetic translation competence, a type of translation which has so far not gained much popularity among translation scholars. The first part of this article offers a concise state of the art of the concept translation competence. Capitalizing on models of translation competence developed by PACTE (Process in the Acquisition of Translation Competence and Evaluation), TransComp and EMT (European Master's in Translation), an original model of cosmetic translation competence is presented along with its sub-competencies. The second part of this article focuses on implications for teaching cosmetic translation. The paper concludes with general remarks pertaining to avenues for future research into cosmetic translation competence and its acquisition.
\end{abstract}

1 https://orcid.org/0000-0002-6508-8432

Uniwersytet w Białymstoku, Katedra Językoznawstwa Porównawczego i Stosowanego

Zakład Translatoryki i Dydaktyki Języków Obcych

b.piecychna@uwb.edu.pl 
Keywords: cosmetic translation, cosmetic translation competence, cosmetic translation competence acquisition, theoretical model, cosmetic translation teaching

\section{Streszczenie}

Wraz z postępującym na całym świecie rozwojem branży beauty na znaczeniu zyskują w ostatnim dziesięcioleciu tłumaczenia kosmetyczne. Zjawisko to przyczynia się do zwiększonego zapotrzebowania na kompetentnych tłumaczy mających odpowiednie umiejętności oraz wiedzę $\mathrm{w}$ rozwiązywaniu problemów, które są charakterystyczne dla przekładu tekstów z zakresu kosmetyki i kosmetologii - mowa zarówno o tłumaczeniach specjalistycznych z tego obszaru, jak i o tych, które wymagają od tłumacza bardziej kreatywnego podejścia. Głównym celem pracy jest przedstawienie i omówienie oryginalnego modelu teoretycznego kompetencji tłumaczeniowej w przekładzie tekstów kosmetycznych - tym rodzaju tłumaczeniu, który nie cieszy się większym zainteresowaniem przekładoznawców. Pierwsza część artykułu przedstawia w zwięzły sposób stan badań nad koncepcją kompetencji tłumaczeniowej (ang. translation competence). Następnie analizie poddany jest innowacyjny, będący tematem niniejszej pracy, model teoretyczny, wzbogacony o listę wchodzących w jego skład subkompetencji. Model ten bazuje na dobrze znanych w przekładoznawstwie projektach grup badawczych PACTE i TransComp oraz na programie dydaktycznym EMT. Druga część artykułu przedstawia implikacje omówionego modelu teoretycznego dla translodydaktyki w przekładzie tekstów kosmetycznych. Artykuł wieńczą ogólne uwagi dotyczące możliwości prowadzenia dalszych badań w zakresie kompetencji tłumaczeniowej w przekładzie kosmetycznym oraz procesu jej nabywania.

Słowa kluczowe: przekład kosmetyczny, kompetencja tłumaczeniowa w przekładzie kosmetycznym, akwizycja kompetencji tłumaczeniowej w przekładzie kosmetycznym, model teoretyczny, translodydaktyka w przekładzie tekstów kosmetycznych

\section{Introduction}

Translation competence (further referred to as TC) has received much attention in recent years. This is due to the growing popularity of translation courses offered both at undergraduate and postgraduate levels and translation scholars' attempts at developing trainees' skills and abilities in accordance with the requirements delineated by the translation industry. Although the notion of TC has been an object of research since the 1990s, the first proposals to define the concept appeared as early as the 1970s (e.g. Wills, 1976; Harris, Sherwood, 1978). These first approaches to TC were aligned with the then developing theories of language acquisition and of bilingualism (Pym, 2003).

TC is usually defined as a collection of skills and abilities necessary for completing a translation task. Such multi-componential theoretical models of TC became extremely popular after translation studies had been finally regarded as a separate discipline on its own (see Pym, 2003, p. 483). The multi- 
componential approach has now been well established and usually comprises source and target language knowledge, knowledge of different text and discourse types, domain knowledge, knowledge of the translation process, as well as the ability to use translation tools and to transfer a text from the source language into a text in the target language (see e.g. Bell, 1991; Campbell, 1991; Neubert, 2000; Presas, 2000; Risku, 1998; Shreve, 2006). An interesting aspect of TC has been introduced by Kelly (2005, p. 33-34), who added components pertaining to attitudinal (psycho-physiological) and interpersonal skills. Although the multi-componential perspective has been levelled with criticism (see Pym, 2003), consensus has been reached among translation scholars that the standard list of competencies as delimited above should serve as a point of departure for discussions on translator training methodology in accordance with the specificity of the translation profession.

TC has also been investigated from a minimalist perspective as the ability to produce a large number of translations and to select only that version which the translator is able to deem as the most appropriate with "justified confidence" (Pym, 2003, p. 489-490). However, the minimalist approach has been found to be too simplistic in order to reveal the inherent intricacies and complexity that the translation process necessarily entails (Whyatt, 2012, p. 164-165).

Translation studies literature contains a plethora of remarks pertaining to the skills that a competent translator should possess. References to TC can be made implicitly or explicitly in such papers or monographs, and can also revolve around the components mentioned above, often from the perspective of the requirements for the quality of translation services as observed within the translation market (see e.g. Englund Dimitrova, 2005; Gile, 1995; Gouadec, 2007; Kiraly, 2000; Koller, 1979; Nord, 1991; Robinson, 2003; Snell-Hornby, 1992; Wills, 1982; Wills, 1996). Apart from this componential perspective attempts have also been made to address TC from a hermeneutical standpoint (see, e.g., Bukowski, 2012; Stolze, 2015). In addition, there have been papers pertaining to specific skills being part of TC, for example linguistic, extralinguistic, 'mining', knowledge of a particular domain etc. (for a brief overview see PACTE, 2003, p. 46-47).

All the above mentioned proposals, however, are generic in nature, that is, they relate, in way or another, to TC as delimited in relation to general translation, rather than specialized. Over the years, there have been scarce attempts to develop theoretical models of TC as pertaining to a given area of specialized translation. For example, Prieto Ramos (2011) and Piecychna 
(2013) have shown the necessity for and considerable significance of creating theoretical models of TC with an emphasis on legal translation because of the specificity of this type of transfer.

Despite this considerable research gap, it is worth noticing that in many papers translation scholars do imply the specificity of specialized TC by reflecting upon the nature of skills that the translator of texts belonging to a given domain should possess (see e.g. Cao, 2007, p. 37-52; Montalt Resurrecció, González Davies, 2014, p. 34-44). Developing specific models of TC should be of no surprise as it is specialization which is one of the most important factors influencing "variations in translation competence" (PACTE, 2003, p. 48). Furthermore, with an incessant growth of the cosmetic industry and its everincreasing value (for more see https:/www.statista.com/topics/3137/cosmeticsindustry/), which is expected to grow even bigger in the forthcoming years (https://www.fiormarkets.com/report/beauty-and-personal-care-products-

market-by-product-407144.html), there has been (and will be) a need for commissioning competent translators specializing in the area of cosmetics and beauty products - whether their core discipline is translation studies or cosmetology.

Capitalizing on well-established theoretical models of TC (PACTE, TransComp, EMT), the present paper discusses a set of sub-competencies forming cosmetic translation competence (further referred to as CTC). These sections lay the theoretical foundation of implications for translator training with a special focus on skills and abilities that the translation trainee should acquire within the area of cosmetic translation. The paper concludes with reflections upon further strands of research that should be conducted on the notion of CTC and its acquisition.

\section{Models of TC}

As mentioned, this paper builds on three well-known theoretical and pragmatic models of TC: PACTE, TransComp and EMT. They serve as a starting point in the further discussion of sub-competencies forming CTC. They were selected as points of departure for developing CTC model because their frameworks are marked by a detailed nature, they approach the issue of TC from a didactic and professional perspective, two of them (PACTE and TransComp) are empirically grounded, and the hypotheses the two groups had posed were then tested and verified in a series of experimental studies. 
Also, the three models are already well-grounded and widely accepted in translation studies.

\subsection{PACTE group's translation competence model}

PACTE group, whose participants include: Allison Beeby, Mònica Fernández, Olivia Fox, Amparo Hurtado Albir, Anna Kuźnik, Wilhelm Neunzig, Patricia Rodríguez, Lupe Romero and Stefanie Wimmer (Facultat de Traducció i d'Interpretació of the Universitat Autònoma de Barcelona), have been working on their model of TC since 1997 (although they formally registered as a research group in 2002). The general assumption behind the model had been that TC was a communicative activity which aimed at making decisions and solving problems, and that it required expert knowledge (PACTE, 2003, p. 43-44). This definition was later formulated as "the underlying knowledge system needed to translate" (PACTE, 2005, p. 610). The PACTE model is a typical multi-componential set of skills and abilities that a competent translator should acquire in order to produce a high-quality rendition. It comprises both types of knowledge: declarative and procedural, with the latter being predominant in the translation process (PACTE, 2003, p. 58).

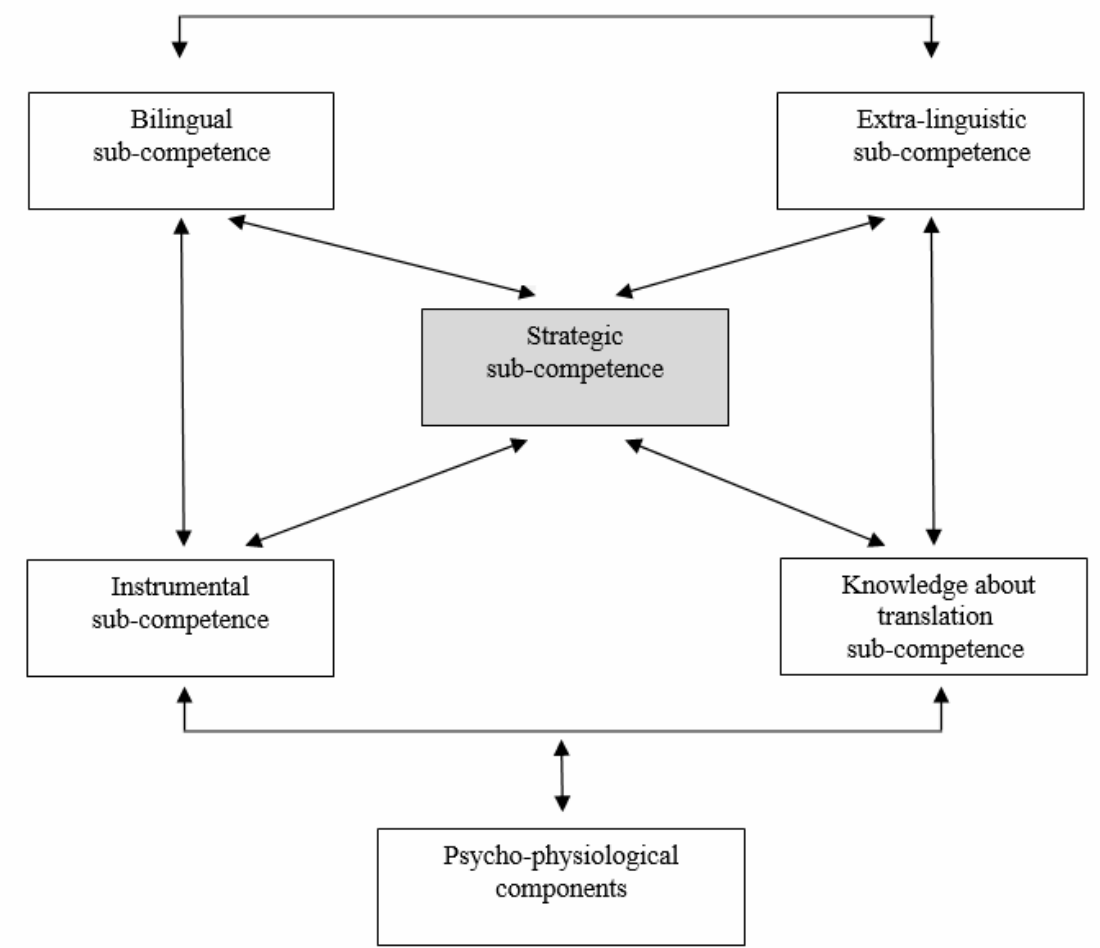

Figure 1. PACTE group's TC model (PACTE, 2008, p. 107) 
At the heart of the model lies strategic sub-competence, which controls, activates and verifies the quality of the translation process. It also monitors the functions and mechanism of the other sub-competencies: bilingual (knowledge of two languages), extra-lingual (knowledge of the cultural conditioning of the language pair between which the translator mediates), instrumental (procedural knowledge of the use of translation tools and translation technology), knowledge about translation, and psychophysiological aspects (such as memory, emotions, creativity, logical reasoning, etc.) (PACTE, 2003, p. 58-59).

\subsection{Suzanne Göpferich's translation competence model}

A more developed form of PACTE group's approach to TC is TransComp project led by Susanne Göpferich. This project focuses even more on didactic and professional aspects of the translation process than the previous one. The model capitalizes on Hönig's concept of the ideal translation and the PACTE proposal.

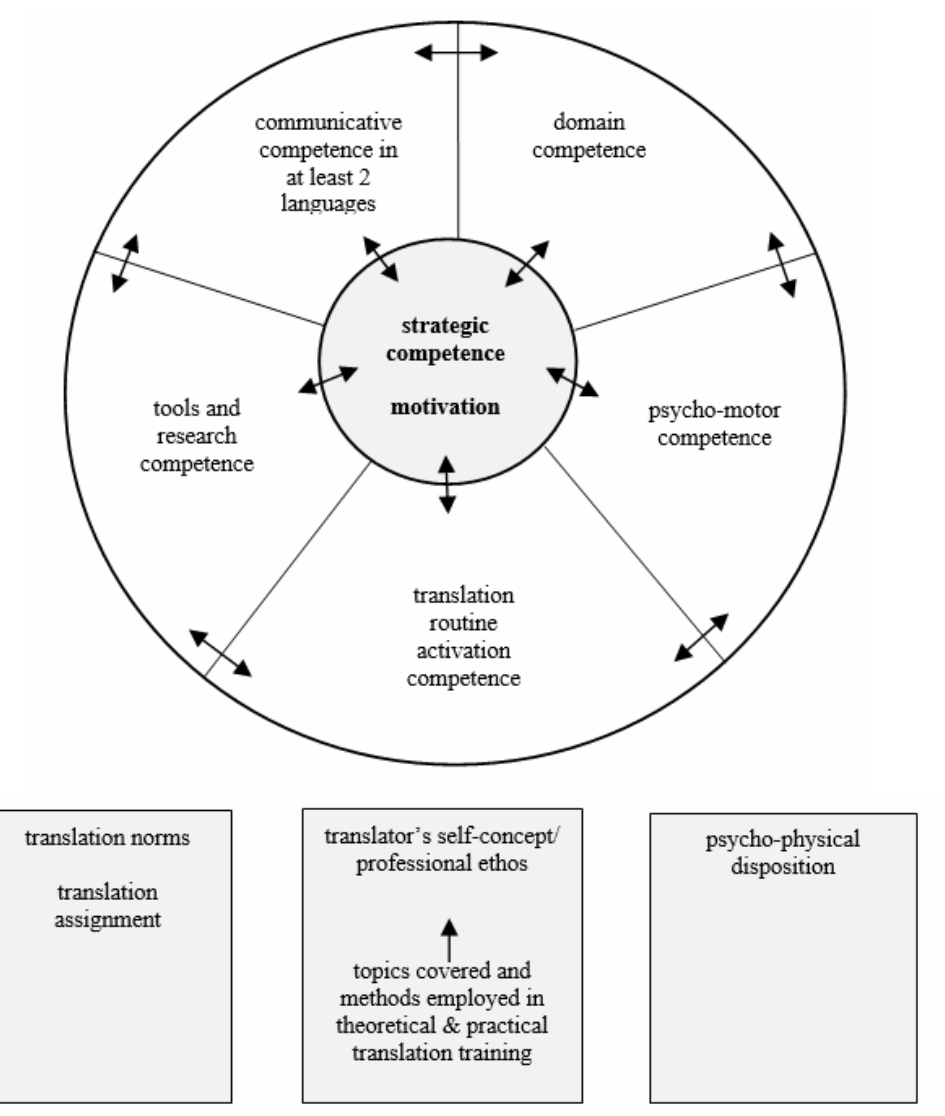

Figure 2. Susanne Göpferich’s translation competence model (Göpferich, 2009, p. 21) 
As can be seen above, the model comprises six main elements, which share many features with the sub-competencies developed by PACTE group. For instance, communicative competence in at least 2 languages corresponds to PACTE group's bilingual sub-competence, and tools and research competence bears close resemblance to instrumental sub-competence. Also, the most significant component of TransComp model, as in PACTE group's, is strategic competence, which controls the other elements of the model and influences the translator's decision as to the selection of macrostrategy to be deployed in the translation process at any given time. Interestingly, as Göpferich (2009) states, the rate at which translation competence develops, can be conditioned by psycho-physiological aspects of the translator's behaviour (p. 21-23).

Let us briefly discuss the other competencies of the model. Communicative competence in at least 2 languages relates to knowledge of various aspects of the functioning of language, including, but not limited to, lexis, grammar, semantics or pragmatics. Domain competence is associated with knowledge (general and specialized) that the translator should possess in order to both understand the source text and render it in a different language. Tools and research competence refers to the ability to use both conventional and non-conventional sources of information relevant to the translation process. Translation routine activation competence is connected with the use of microstrategies. It exerts an impact on the translator's way of handling concrete chunks of text as it relates to the already learned translational behaviour. Psycho-physiological competence comprises skills relating to reading and writing, necessary for the realization of the translation task. According to Göpferich (2009), the main difference between bilingual competence and translation competence lies in the latter including the component of strategic competence, coupled with intrinsic and extrinsic motivation, demonstrating the translator's skills and abilities to handle the translation process, the component of tool and research competence and the component of translation routine activation (p. 30).

Göpferich's model of TC accentuates those factors that exercise an impact on the level of TC. These include: the translator's self-concept and professional ethos, translation norms and specifications as well as psycho-physiological disposition (e.g. faith in one's own abilities or intelligence). In this sense TransComp model lies at the intersection of both didactic and professional domains in that its specificity is shaped by the translation market expectations of translation trainees, and at the same time it has a bearing on translation teaching methodology in its two dimensions: practical and theoretical. 


\subsection{EMT Expert Group's translation competence model}

The last model on which this paper capitalizes is the European's Master in Translation project, a reference framework whose creation has in recent years had a significant impact on training prospective translators within the structures of the EU. The model stipulates "a list of competences that should be acquired by the end of an EMT-eligible training programme" (EMT Expert Group, 2009, p. 1-2).

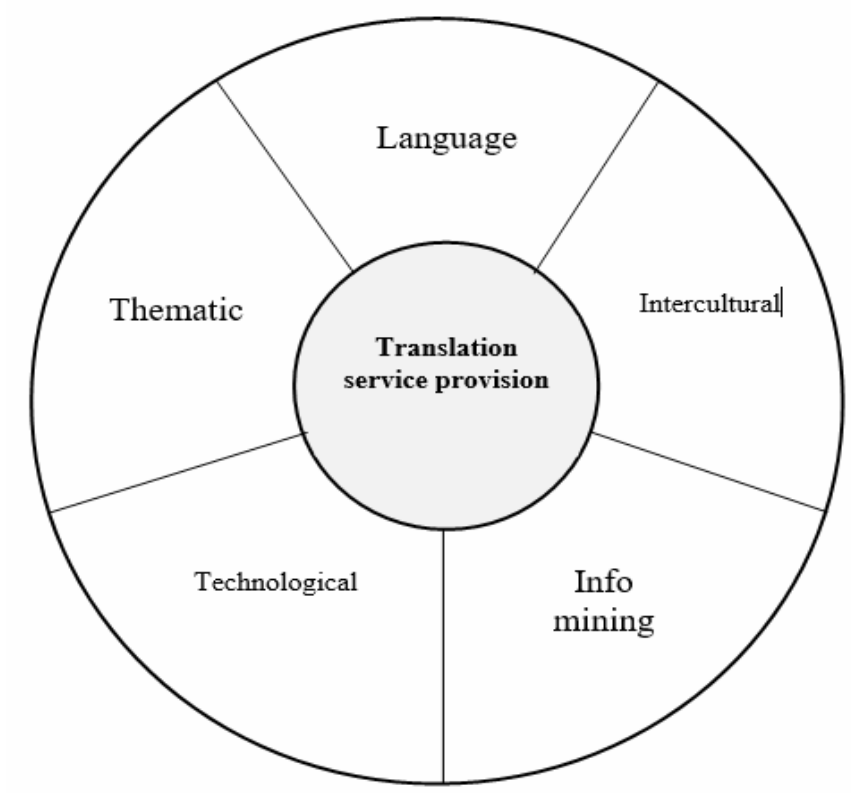

Figure 3. "Wheel of Competence". EMT Expert Group's translation competence model from 2009 (EMT Expert Group, 2009, p. 4)

TC is discussed in this model predominantly within the framework of translation teaching and the requirements determined by the translation industry. TC is here defined as a "combination of aptitudes, knowledge, behaviour and know-how necessary to carry out a given task under given conditions" (EMT Expert Group, 2009, p. 3). The model was reconsidered and reshaped in 2017 "in the light of the changes which have affected both the language industries and European universities" (EMT Expert Group, 2017, p. 2), and now it stands still until 2024. As can be read in the document, the main objective of the initiative is to "consolidate and enhance the employability of graduates of Master's degree in translation throughout Europe" (ibid., p. 3), with the aim of such Master's degree programmes of teaching "a combination of knowledge and skills, which will enable students to achieve the competences 
considered essential for access to the translation industry and to the wider labour market" (ibid., p. 4).

Accordingly, competence is defined as "the proven ability to use knowledge, skills and personal, social and/or methodological abilities, in work or study situations and in professional and personal development" (ibid., p. 3). The model of TC capitalizes on the pragmatic assumption that the translation process is undertaken to fulfil needs of a social, institutional or individual nature, and that the main purpose of training prospective translators is to equip them with the knowledge and skills pertaining to the realization of any translation task up to the required professional standards (ibid., p. 4). The framework comprises the following areas: language and culture, translation, technology, personal and interpersonal, and service provision. The five areas "should be considered as complementary and equally important in providing the translation service, which is the ultimate goal of the translation process" (ibid., p. 5).

The whole model is very elaborate, with each component being divided into further lists of detailed skills and abilities that a future translator should acquire in order to enhance his/her employability. Discussing the concept in its entirety would definitely go beyond the scope of this paper; therefore, let us only refer to the main elements of the framework and their characteristics.

The first area comprises "transcultural and sociolinguistic awareness and communicative skills" (ibid., p. 6). Interestingly, in the previous version of the framework language and culture were separated and regarded as two different components (language competence and intercultural competence). The area of language and culture is here treated as "the driving force behind all the other competences" (ibid., p. 6), constituting an indispensable element of the translation process, an aspect which makes it possible for the procedure to happen at all. Although all the other elements of the framework are referred to as complementary, it seems that it is language and culture area that sets translational activities in motion. The second area, called translation, comprises strategic, methodological and thematic competence. As the document puts is, " $\mathrm{t}]$ ranslation competence lies at the heart of the translation service provision competences" (ibid., p. 7), and it encompasses all the translator's decisions made from the beginning of the translation process, including source text and translation brief analysis, until quality control. The third area, technology, relates to "tools and applications" (ibid.: 9). This component is self-explanatory as it is associated with the use of all the translation technologies at the translator's disposal, including machine translation technologies, which 
might enhance the translation process. The next area, referred to as personal and interpersonal, "includes all the generic skills, often referred to as 'soft skills" (ibid., p. 10). This type of competence encompasses abilities to work in a team, plan and manage tasks, meet deadlines, use social media in a professional environment, and engage in the process of personal development (ibid.). The last area, service provision, relates to "all the skills relating to the implementation translation . . . in a professional context - from client awareness and negotiation through to project management and quality assurance" (ibid., p. 11). It comprises skills and abilities to communicate and negotiate with clients; follow the latest translation market requirements; organize translation projects, including, but not limited to, budget, time planning, roles dividing; follow ethical principles and values specific to the translation profession; and take care of the quality of translation products.

The three TC models discussed above serve as a point of departure for the further discussion on CTC. Some elements from the models will be duplicated; however many components will be specific to cosmetic translation only, thus making the proposed model unique as juxtaposed against other wellestablished theoretical frameworks of TC.

\section{Towards a theoretical model of cosmetic translation competence (CTC)}

On the basis of the three TC models discussed above, a tripartite CTC model is presented. The division of the model into three separate, albeit complementary, parts seems to be necessary in order to reveal the complex nature of the field of cosmetic translation, which by its very nature encompasses both specialized genres (e.g. research articles or cosmetic product specifications) and those requiring more creativity-oriented translational activity (e.g. perfume descriptions or slogans). 


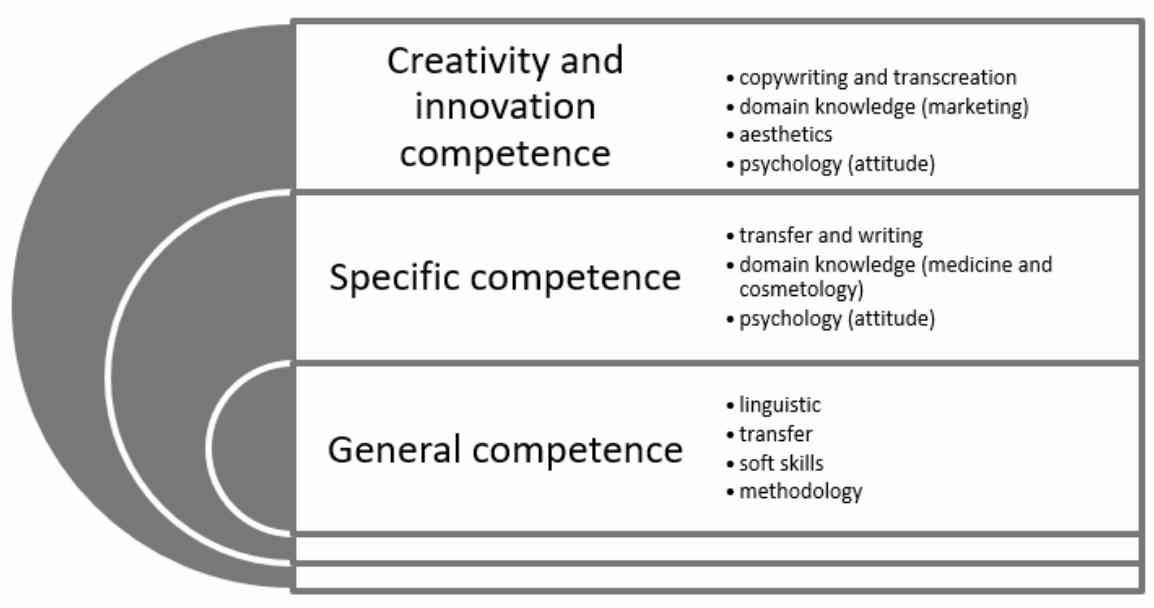

Figure 4. My cosmetic translation competence model

\subsection{General competence}

As illustrated in Fig. 4, the first part relates to general competence which characterizes all types of translation irrespective of a type of text the translator renders. Linguistic competence comprises a thorough knowledge of at least two languages. The phrase thorough knowledge refers to pragmatic, semantic, lexical, syntactic and morphological dimensions of language. It is vital to differentiate, after Göpferich (2009), linguistic competence in the source language, which is necessary for decoding the source message, and linguistic competence in the target language, which makes it possible to create a text in harmony with norms prevailing within the area of the proper usage of mother tongue in terms of orthography, punctuation, stylistics, lexis and grammar. The two sub-competencies complement each other. It is also worth underlining that in this model, linguistic competence encompasses cultural knowledge as it is assumed that language is an indispensable element of culture, and thus it both represents culture and is the driving force behind multifarious cultural manifestations.

The next area pertains to transfer sub-competence, which comprises the ability to use knowledge and other skills associated with the translation process at any given time. This sub-competence revolves around the translator's decisions as well as translation solutions and microstrategies he/she adopts in order to handle translation problems with relation to specific fragments of text. Transfer sub-competence also requires the ability to deploy translation tools, including technology, and to search for necessary information on a regular basis, which means that tools and research competence (or 
instrumental sub-competence), differentiated by Göpferich and PACTE as separate elements, is here treated as an inherent part of transfer subcompetence. As can be observed, domain, or thematic, knowledge has been transposed in this model into the other components of the framework as it should here be regarded as specific to cosmetic translation.

The third area of the first component of the model is called soft skills, and corresponds to the personal and interpersonal section in the EMT framework. As in the model by EMT Expert Group, this area encompasses the ability to manage translation commissions, plan time, comply with the requirements set by the commissioner, work in teams and cooperate, as well as handling problems connected with the realization of the translation task.

The last area is referred to as methodological sub-competence. As in the PACTE and TransComp projects, this component controls the course of the translation process in its entirety and exerts an impact on the translator's choice of macrostrategy for dealing with the commission at hand.

\subsection{Specific competence}

The second part of the framework pertains to sub-competencies of a higher order. These are those sub-competencies which are necessary for translating cosmetic and cosmetological texts requiring specialized thematic knowledge, often medical, and specific terminology (for instance, research articles within the field of cosmetology, cosmetic labels, cosmetic product specifications, findings of cosmetological studies, descriptions of physiotherapeutic treatment, and manuals of specialized equipment). The whole component is referred to in the model as specific competence. Due to the specialization of this type of texts, it is assumed that their translation requires from the translator more complex skills and abilities than the previous two components. The sub-competencies include the following areas: transfer and writing, domain knowledge (which also encompasses the use of translation tools, and professional practice) and psychology.

Transfer and writing sub-competence relates to knowledge of the genre conventions and various registers in the language pairs involved, norms prevailing among different types of readership, as well as specific cosmetological, (bio)chemical and medical terminology and phraseology. This type of sub-competence is also associated with knowledge of in-house stylistic conventions specific to a given publishing house or a journal in which 
a translation is to be published. Transfer and writing sub-competence is complemented by domain knowledge sub-competence, which pertains to cosmetology-specific knowledge, including, but not limited to, the theory and application of beauty treatment, chemistry, dermatology or common skin conditions, and additionally to knowledge of specific cultural differences among the potential receiving audience of a given translation. It has to be noted after Göpferich (2009: 22) that this sub-competence also includes the translator's skills to identify his/her own lack of knowledge in a given area and understanding how to fill the gaps. Accordingly, domain knowledge is necessarily connected with the skills and abilities to search for all kinds of cosmetological information in available sources and to cooperate with relevant experts in the field if need be.

Psychology sub-competence pertains to the translator's general attitude towards his/her job with a special focus placed on self-development within the area of cosmetology, as well as with respect to the ongoing changes in the cosmetic translation market requirements of translators.

\subsection{Creativity and innovation competence}

The last part of the model is of yet higher order than the previous ones, and it refers to the translator's knowledge, skills and abilities to produce renditions of a creative nature, oftentimes completely novel texts, as they often comprise product descriptions, slogans, sponsored content or press releases. It is referred to in this model as creativity and innovation competence. This component of the CTC framework lies at the intersection of marketing translation and transcreation, and as such involves sub-competences pertaining to both services. It includes the following areas: copywriting and transcreation subcompetence, knowledge of marketing sub-competence and aesthetic subcompetence.

Copywriting and transcreation sub-competence comprises a perfect command of at least two languages, although it is knowledge of mother tongue which remains of the utmost importance to the quality of the copy. Knowledge of a foreign language is pivotal because the copywriter should also be able to find relevant information on English websites pertaining to the rules for creating persuasive texts. More importantly, this component refers to the ability to use persuasive, engaging, creative and emotive language which exerts a significant impact of the customer's decision to purchase a given 
product. Therefore, a cosmetic translator rendering product descriptions, for example fragrances, must have a vast vocabulary at his/her disposal. Pragmatic knowledge about specific conventions characterizing particular types of marketing copy as well as brands is not without its significance as the copywriter/translator should know which linguistic means to deploy in order to implicitly reveal the philosophy of the brand. What should be neglected is also the translator's willingness to think out of the box and to come up with innovative solutions. Copywriting and transcreation sub-competence also includes the ability to produce transcreations, i.e., texts written on the basis of the source text and suited to the specificity of the receiving audience in terms of the content, emotions and general feel of the message.

Knowledge of marketing sub-competence can be understood as "extralinguistic sub-competence". It pertains to the domain-specific knowledge strictly connected with the area of marketing, and as such is necessary for the translator to understand and implement the criteria for creating relevant and valuable translations (or transcreations). This type of knowledge is mainly declarative in nature and relates to such aspects as the target audience, marketing techniques and strategies as deployed in the cosmetic and beauty products industry, the consumers characteristics and expectations, and transcreation procedure.

Aesthetic (artistic) sub-competence, relevant for the model in question due to the specificity of the cosmetic and beauty products industry, should be understood as translator's skills and abilities to both trigger aesthetic experience in the recipient by means of specific linguistic means, such as similes, metaphors, metonymy, alliteration, personification or phonaesthetics, and to identify such aspects of the source text which exhibit significant predisposition to evoke aesthetic response in the target reader.

Psychology sub-competence pertains to the translator's (or transcreator's) general attitude towards his/her job with a special focus placed on selfdevelopment within the area of marketing and promotion of cosmetic products, as well as with respect to the ongoing changes in the cosmetic translation market requirements of translators and transcreators.

The entire model of CTC deploys both types of knowledge: declarative and procedural. It is assumed that it is procedural knowledge that plays a central role in the delivering of a translation service in the most appropriate 
way and up to the required standards. As mentioned, the model is of a tripartite nature as it neatly connects the following dimensions: general skills and abilities necessary for understanding texts which do not pose terminological or domain challenges, specific skills and abilities which pertain to the area of cosmetic and beauty products industry, and creativity and innovation which relate to the production of texts that do not comply with the translation procedure per se but rather with processes necessitating the creation of texts only inspired by the original texts (as in transcreation). With regard to the above, is should be noted that certain aspects of the three components of the framework do overlap one another. For instance, transfer sub-competence or methodological (strategic) sub-competence from the area of general competence must necessarily occur at the level of specific competence and creativity and innovation competence. Some of the subcompetencies which form general competence are then absorbed in the area of specific competence or creativity and innovation competence. This is because it is assumed, following PACTE group's (2000) remarks, that during the process of the development of translation competence, the integrative competence comes into play, which merges and integrates particular subcompetencies, a process which depends on the translational assignment at any given time (p. 104). Therefore within the notion of general competence three sub-competencies are already integrated into one: transfer sub-competence, tools and research sub-competence and domain knowledge sub-competence. This arises from the presumption that at the stage of the implementation of a course in cosmetic translation, translation trainees should have integrated the three sub-competencies, at least to some extent. Likewise, transfer and writing sub-competence included in the section of specific competence already integrates linguistic competence and the three sub-competencies enumerated above (transfer, tools and research, and domain knowledge). Also, what should be noted is that methodological (strategic) sub-competence is present explicitly within general competence and implicitly in the other components of the model.

Despite the above mentioned unquestionable overlapping and integration, however, the particular components are of a hierarchical nature. Sub-competencies required to translate non-literary, general texts are also needed to render more specialized messages which abound with terminology and professional phraseology. Skills and abilities that a competent cosmetic translator rendering specialized texts should acquire are also often necessary for creating transcreations which might contain specific terms or phrasemes 
typical of cosmetic discourse (as in fragrance descriptions where lists of ingredients containing chemical names need to be often translated). Creativity and innovation competence is situated on top of the hierarchy because it frequently pertains to the process of producing texts which can only be inspired by the content of the source text rather than being directly translated. Although translation and transcreation should be seen as separate services, it has to be noted that these two processes overlap in a professional environment with a line between marketing translation and transcreation being at least blurry.

\section{Implications for translation teaching}

Cosmetic translation overlaps specialized translation (often close to medical translation due to terminological issues in certain types of texts, in particular research papers and cosmetic product specifications) and non-literary general translation with elements of copywriting and transcreation, and therefore cosmetic translator training should include the two pillars. Training components should comprise the theoretical framework to familiarize the trainee with background knowledge within the field of cosmetology, as well the practical framework consisting of as many texts to be translated within the field as possible so as to expose the trainee to the discursive indicators and writing styles typical of each genre. The large number of texts to be covered during such course is of the utmost importance to the development of cosmetic translation competence, but even more significant are trainees' writing skills to be worked on regularly.

The variety of different text genres which are usually translated (or transcreated) for the cosmetic and beauty products industry necessitates the activation of self-reflection, or meta-reflection, in trainees in the first place, a concept whose use "can improve the effectiveness of the learning process by promoting greater self-awareness and self-regulation" (Pietrzak, 2019, p. 416). The self-reflection process should be realized on two levels: reflection on the specificity of a given commission, and reflection on the difficulty of the commission with regard to the potential problems that the trainee might encounter in the actual translation process. Self-reflection, however, should manifest itself not only at the stage of the diagnosis of the source text (its genre, potential problems that might occur, strategies and/or techniques for dealing with the difficulties, consulting experts in the field), but, first and foremost, at the stage of quality control of the translation product. Trainees should be 
taught the criteria to be applied while checking, also along with the trainer, whether the translation products are up to the required standard and whether they stand in harmony with the client's brief (either translational or transcreational).

The three components discussed in the previous section should be taught at Master's degree level, in the hierarchical order in which the particular subcompetences occur. A course in cosmetic translation should be treated as predominantly specialized, and therefore ought to be taught after the trainee has been acquainted with general aspects of the translation process. Before enrolling for the course, then, the trainee should have already acquired general competence, which could be regarded as a foundation for the development of further components: specific competence as well as creativity and innovation competence. It is recommended that cosmetic translation course consist of two main pillars: specialized texts (where a focus is placed on the acquisition of specific competence) and more creative renditions (with an emphasis put on creativity and innovation competence). It is strongly advisable that the trainee be counselled on the choice of one of the paths as they entail different sets of skills and abilities. In other words, despite the fact that the trainee ought to be familiarized with content pertaining to both specialized and more creativityoriented texts (as the prospective cosmetic translator should be exposed to as many cosmetic texts as possible), he/she should also be informed about significant differences between the two areas and about the necessity for sticking to one in a professional environment. In line with the EMT Expert Group framework it is here assumed that "translator education and training at Master's degree level should equip students not only with a deep understanding of the processes [of cosmetic translation] involved, but also with the ability to perform . . . a translation service [of cosmetic translation] with the highest professional ... standards" (EMT Expert Group, 2017, p. 4).

Below there is a table presenting skills and abilities corresponding to each of the sub-competences in the model of CTC. 
Table 1. Areas of competences along with corresponding skills and abilities of the prospective cosmetic translator

\begin{tabular}{|c|c|}
\hline Area of competence & $\begin{array}{l}\text { Sub-competencies along with corresponding skills } \\
\text { and abilities of the prospective cosmetic translator }\end{array}$ \\
\hline General competence & 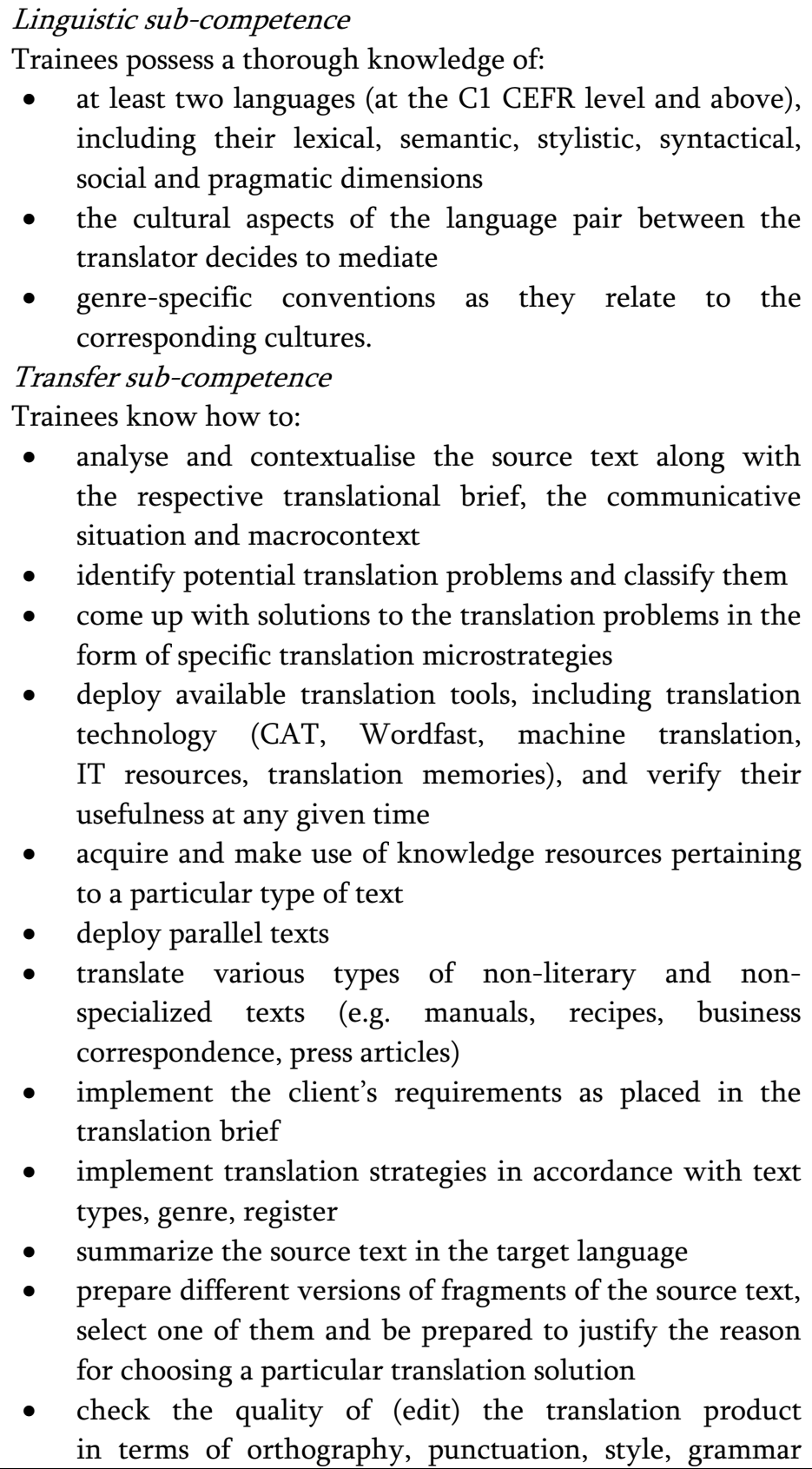 \\
\hline
\end{tabular}




\begin{tabular}{|c|c|}
\hline & $\begin{array}{l}\text { and lexis } \\
\text { Soft skills } \\
\text { Trainees know how to: } \\
\text { - plan and manage the translation process efficiently } \\
\text { and in accordance with the translation norm 17100:2015 } \\
\text { - cooperate with members of their teams } \\
\text { - take care of the atmosphere within the workplace } \\
\text { and of the ergonomics of the working environment } \\
\text { - } \text { respond to feedback in an appropriate and professional } \\
\text { - manner keep to deadlines and the client's instructions } \\
\text { - take care of self-development } \\
\text { Methodological sub-competence } \\
\text { Trainees know how to: } \\
\text { - plan and conduct particular stages of the translation } \\
\text { process in accordance with the translation norm } \\
\text { 17100:2015 } \\
\text { - apply translation macrostrategies in accordance with text } \\
\text { types, genre, register, client's specifications, the } \\
\text { - respective communicative situation and macrocontext } \\
\text { assess the correctness and functionality of a chosen } \\
\text { macrostrategy } \\
\text { prioritise translational procedures while applying } \\
\text { the selected macrostrategy } \\
\text { verify the adequacy of the translation }\end{array}$ \\
\hline Specific competence & $\begin{array}{l}\text { Transfer and writing sub-competence } \\
\text { Trainees know how to: } \\
\text { - identify, characterize and create coherent and cohesive } \\
\text { texts within the cosmetological discourse and } \\
\text { in harmony with the prevailing norms and genre } \\
\text { conventions } \\
\text { - plan and conduct particular stages of the translation } \\
\text { process in accordance with the translation norm } \\
\text { 17100:2015 } \\
\text { apply translation macrostrategies in accordance with text } \\
\text { types, genre, register, client's specifications, the } \\
\text { respective communicative situation and macrocontext } \\
\text { analyse and contextualise the source text in terms of its } \\
\text { macrocontext, coherence and cohesion, translation brief, } \\
\text { communicative situation, cosmetological genre } \\
\text { and branch of cosmetology }\end{array}$ \\
\hline
\end{tabular}




\begin{tabular}{|c|c|}
\hline & 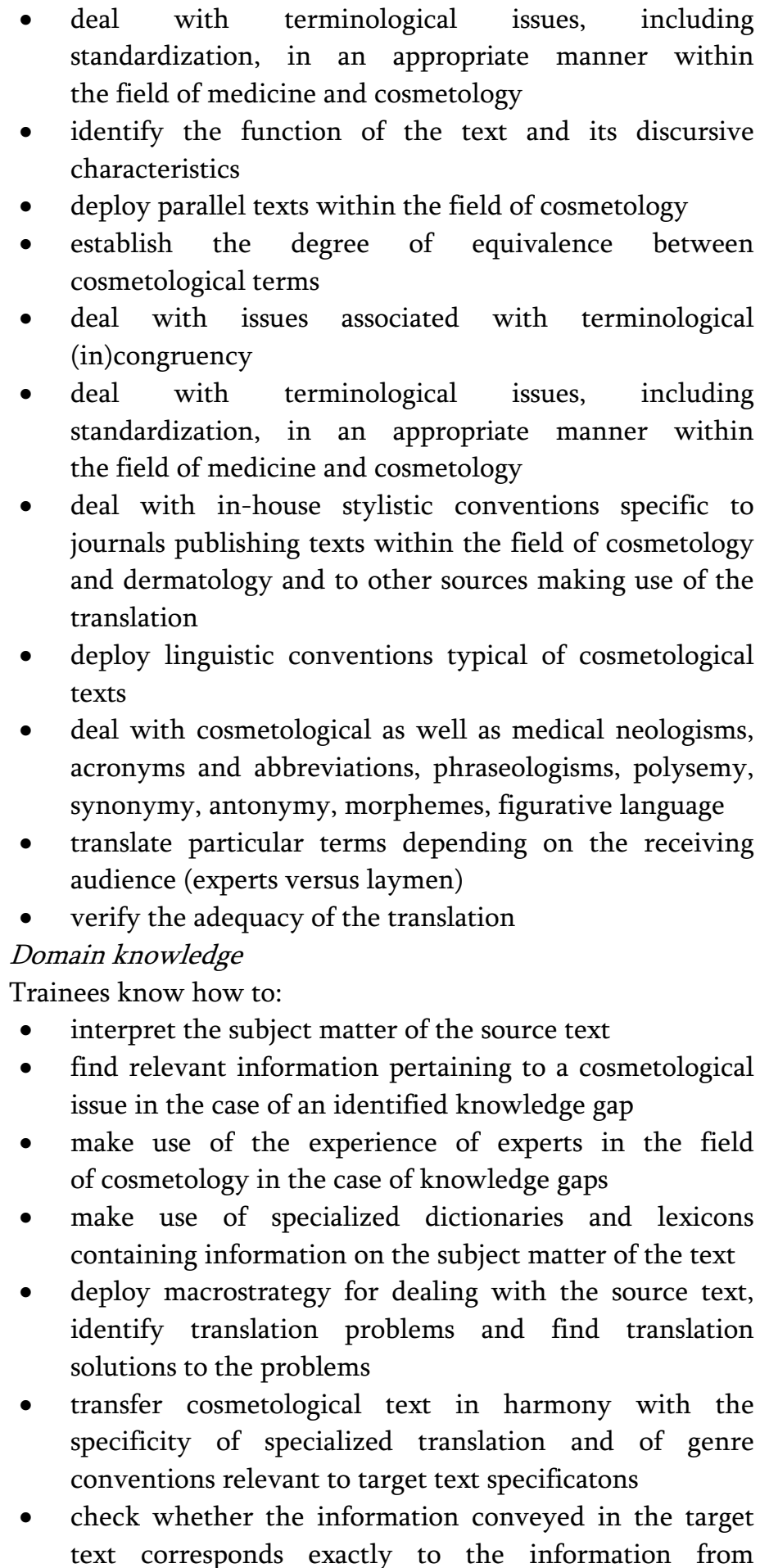 \\
\hline
\end{tabular}




\begin{tabular}{|c|c|}
\hline & 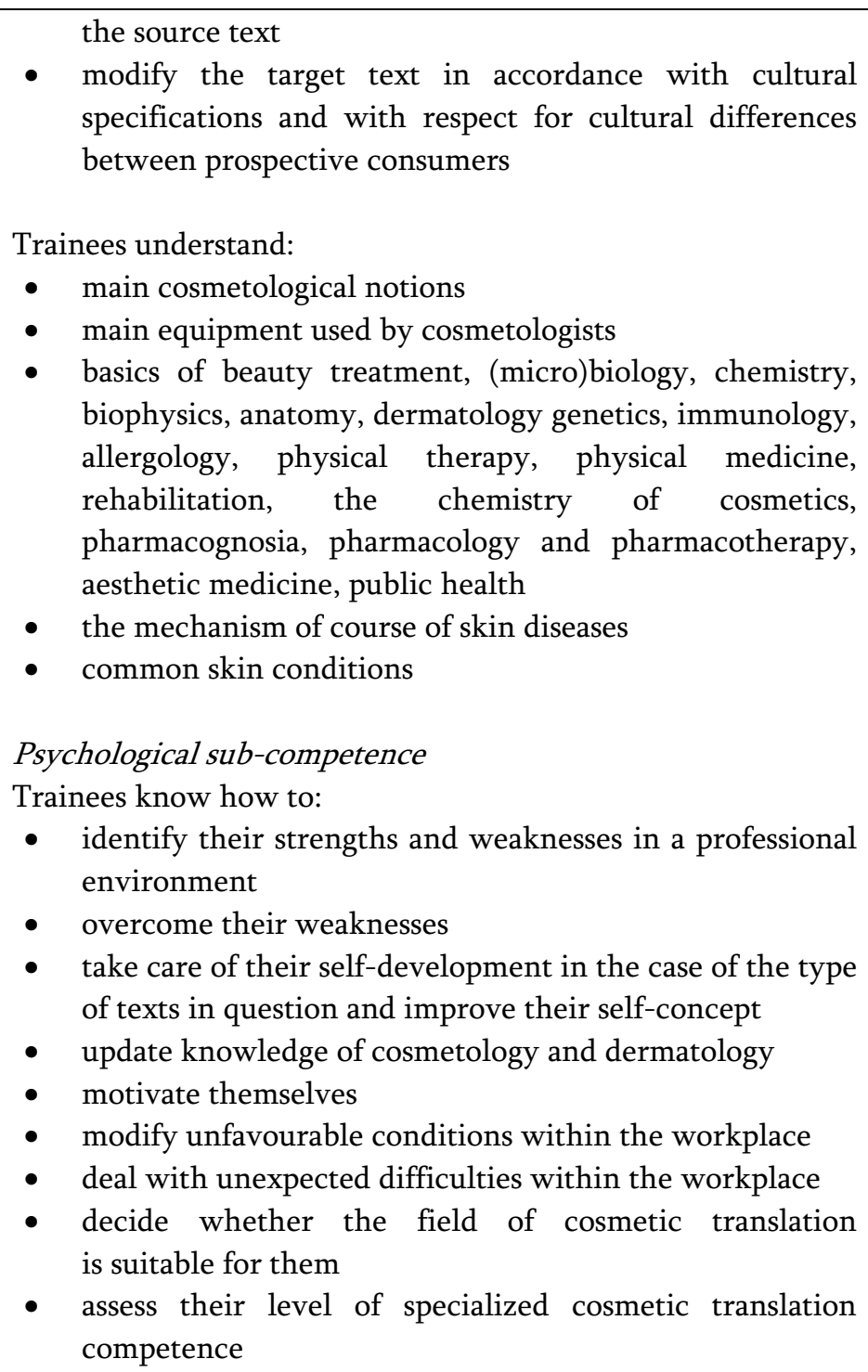 \\
\hline $\begin{array}{l}\text { Creativity and } \\
\text { innovation } \\
\text { competence }\end{array}$ & $\begin{array}{l}\text { Copywriting and transcreation sub-competence } \\
\text { Trainees know how to: } \\
\text { - produce persuasive and creative copies whose content is } \\
\text { emotionally engaging and exerts a significant impact on } \\
\text { the consumer's decision to purchase a given cosmetic } \\
\text { product } \\
\text { - establish macrostrategies for dealing with particular } \\
\text { commissions } \\
\text { - plan and conduct particular stages of the translation, }\end{array}$ \\
\hline
\end{tabular}




\begin{tabular}{|c|c|}
\hline & 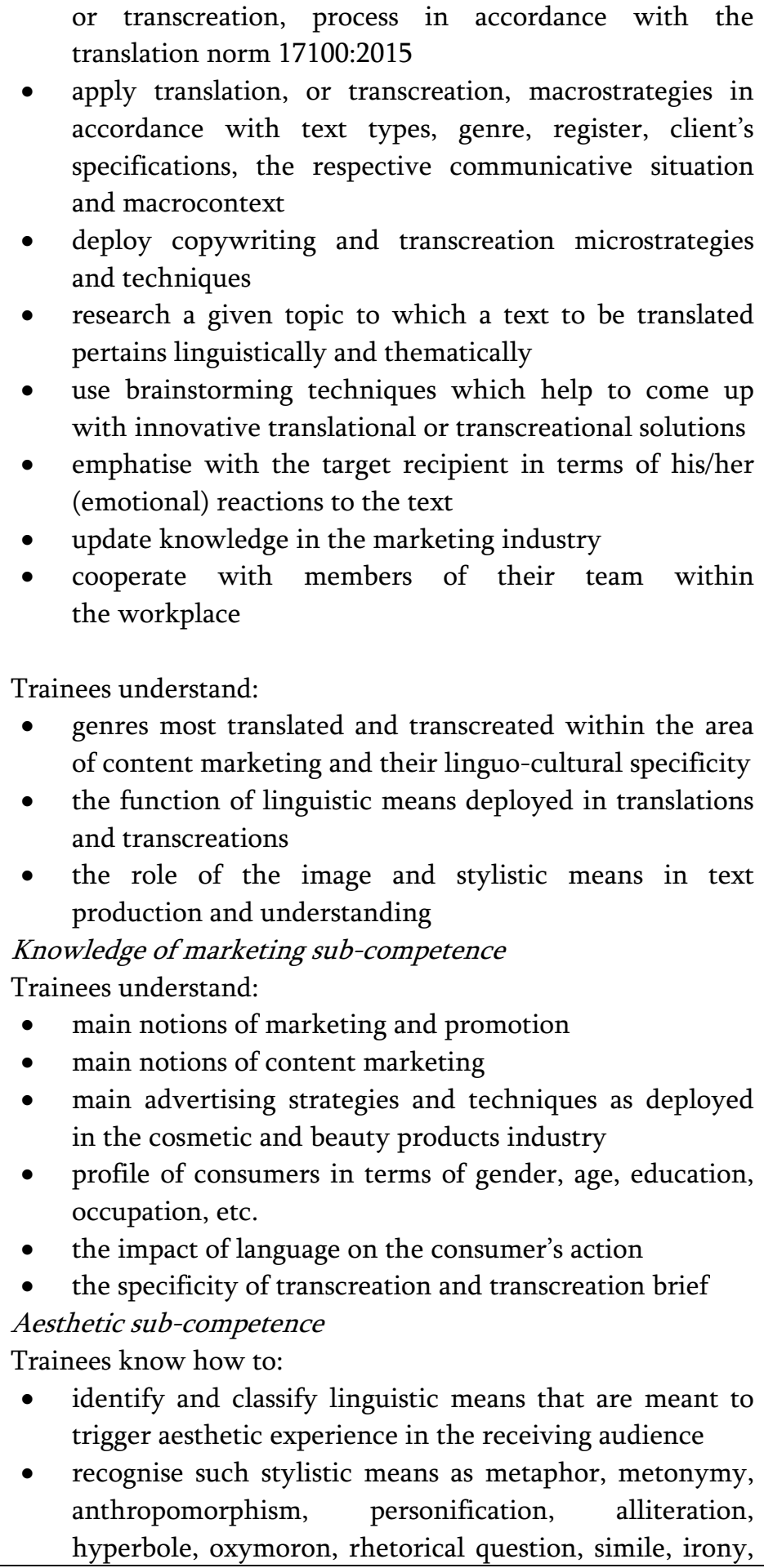 \\
\hline
\end{tabular}




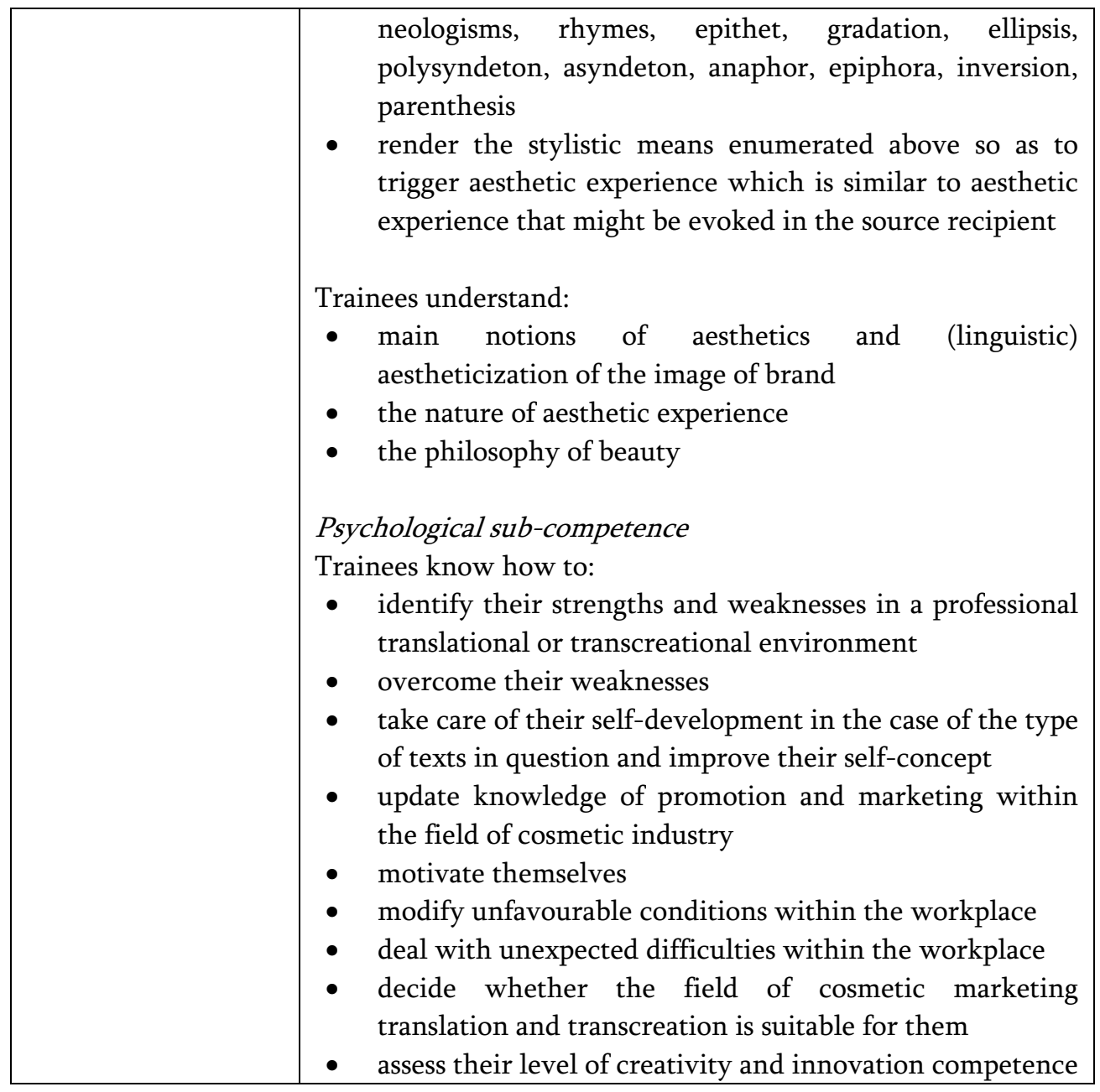

\section{Summary and concluding remarks}

The main objective of this paper was to present and discuss a theoretical model of CTC and its implications for translator training with a special emphasis on texts from the field of the cosmetic and beauty products industry. It has long been stated that TC comprises much more that only the ability to use two (or more) languages and that a competent translator should also possess a broad knowledge of cultural issues specific to the language pair between which they translate, of terminology characteristic of a given domain, of technology and IT applications deployed for translational purposes, of various text types and genres used for a given translational purpose, etc. This obvious statement 
finds its full confirmation in the theoretical proposal of CTC presented in this paper. The framework includes the following three elements: general competence, specific competence, and creativity and innovation competence.

The model has shown that CTC differs from generic models of TC as exemplified by PACTE group, TransComp or EMT Expert Group in that it integrates knowledge, skills and abilities specific to both translation per se and transcreation, as well as general translation and specialized translation. The model also suggests an approach to cosmetic translator training which should aim at integrating both types of knowledge: declarative and procedural, and at conducting formal interdisciplinary training offered in an academic environment, preferably by trainers who specialize in both translation studies and cosmetology, or in translation studies (with a special emphasis on marketing translation) and copywriting.

The suggested model points to its inherent complexity as it refers to such domains and disciplines as medicine, pharmacology, molecular biology, chemistry, linguistics and marketing. This is the first theoretical paper on CTC exclusively, and it has gone some way towards enhancing our understanding of the specificity of cosmetic translation as well as the importance of developing specific translation competence models. Further research should be done to investigate the process of CTC acquisition in both domains: specialized CTC (as in research papers or specifications of creams) and more creative (as in descriptions of fragrances) as these two areas require different subcompetencies and a different nature of expertise. There is abundant room for further progress in determining the scope of declarative and procedural knowledge that a cosmetic translator should possess in order to translate competently. Several questions remain unanswered at present regarding specific translator training models that could be applied in the case of texts within the field of cosmetics and beauty products. Ideally, longitudinal studies are expected, which can become useful in generating and verifying hypotheses pertaining to the process of cosmetic translation competence acquisition in its two dimensions: specialized and transcreational.

\section{REFERENCES}

Bell, R. T. (1991). Translation and Translating. Theory and Practice. London/New York: Longman.

Bukowski, P. (2012). Hermeneutyczne kompetencje tłumacza. In: M. Piotrowska, A. Czesak, A. Gomola A. \& S. Tyupa (Eds.) Kompetencje tłumacza (pp. 125-130). Kraków: Tertium. 
Campbell, S. J. (1991). Towards a Model of Translation Competence. Meta: Translator's Journal 36 (2-3), 329-343. doi: 10.7202/002190ar

Cao, D. (2007). Translating Law. Topics in Translation 33. Clevedon/Buffalo/Toronto: Multilingual Matters LTD.

EMT Expert Group (2009). Competences for Professional Translators, Experts in Multilingual and Multimedia Communication. Retrieved 24 June, 2020 from: https://ec.europa.eu/info/ sites/info/files/emt_competences_translators_en.pdf

EMT Expert Group (2017). European Master's in Translation. Competence Framework 2017. Retrieved 24 June, 2020 from: https://ec.europa.eu/info/sites/info/files/emt_competence fwk_2017_en_web.pdf

Englund Dimitrova, B. (2005). Translation as Text (Re)production. In: B. Englund Dimitrova (Ed.) Expertise and Explicitation in the Translation Process (pp. 9-64). Amsterdam/Philadelphia: John Benjamins.

Fior Markets. (n.d.). Retrieved from https://www.fiormarkets.com/report/beauty-and-personalcare-products-market-by-product-407144.html (2020, June 24).

Gile, D. (1995). Basic Concepts and Models for Interpreter and Translator Training. Amsterdam/Philadelphia: John Benjamins.

Göpferich, S. (2009). Towards a Model of Translation Competence and Its Acquisition. The Longitudinal Study 'TransComp'. In: S. Göpferich, A. L. Jakobsen \& I. M. Mees (Eds.) Behind the Mind: Methods, Models and Results in Translation Process Research (pp. 11-37). Copenhagen: Samfundslitteratur.

Gouadec, D. (2007). Translation as a Profession. Amsterdam/Philadelphia: John Benjamins.

Harris, B. \& Sherwood, B. (1978). Translating as an Innate Skill. In: D. Gerver \& H. Wallace Sinaiko (Eds.) Language, Interpretation and Communication (pp. 155-170). NATO Conference Series. Boston, NA: Springer.

Kelly, D. (2005). A Handbook for Translator Trainers. Manchester: St. Jerome.

Kiraly, D. C. (2000). A Social Constructivist Approach to Translator Education. Empowerment from Theory to Practice. Manchester: St. Jerome.

Koller, W. (1979). Einführung in die Übersetzungswissenschaft. Heidelberg: Quelle \& Meyer.

Montalt Resurrecció, V. \& González Davies, M. (2014). Medical Translation Step by Step. Learning by Drafting. London/New York: Routledge.

Neubert, A. (2000). Competence in Language, in Languages, and in Translation. In: B. J. Adab \& Ch. Schäffner (Eds.) Developing Translation Competence (pp. 3-18). Amsterdam/Philadelphia: John Benjamins.

Nord, Ch. (1991). Text Analysis in Translation Theory, Methodology and Didactic Application of a Model for Translation-Oriented Text Analysis. Amsterdam: Rodopi.

PACTE (2000). Acquiring Translation Competence: Hypotheses and Methodological Problems in a Research Project. In: A. Beeby, D. Ensinger \& M. Presas (Eds.) Investigating Translation (pp. 99-106). Amsterdam/Philadelphia: John Benjamins.

PACTE (2003). Building a Translation Competence Model. In: F. Alves (Ed.) Triangulating Translation: Perspectives in Process Oriented Research (pp. 43-66). Amsterdam/Philadelphia: John Benjamins.

PACTE (2005). Investigating Translation Competence: Conceptual and Methodological Issues. Meta: Translator's Journal 50 (2), 609-619. doi: 10.7202/011004ar

PACTE (2008). First Results of a Translation Competence Experiment "Knowledge of Translation« and »Efficacy of the Translation Process«. In: J. Kearns (Ed.) Translator 
and Interpreter Training. Issues, Methods and Debates (pp. 104-126). New York/London: Continnum.

Piecychna, B. (2013). Legal Translation Competence in the Light of Translational Hermeneutics. Studies in Logic, Grammar and Rhetoric 34 (47), 141-159. doi: 10.2478/slgr-2013-0027

Pietrzak, P. (2019). Scaffolding student self-reflection in translator training. Translation and Interpreting Studies 14(3), 416-436. doi: 10.1075/tis.18029.pie

Presas, M. (2000). Bilingual Competence and Translation Competence. In: B. J. Adab \& Ch. Schäffner (Eds.) Developing Translation Competence (pp. 19-31). Amsterdam/ Philadelphia: John Benjamins.

Prieto Ramos, F. (2011). Developing Legal Translation Competence: An Integrative ProcessOriented Approach. Comparative Legilinguistics - International Journal for Legal Communication 5, 7-22.

Pym, A. (2003). Redefining Translation Competence in an Electronic Age. In Defence of a Minimalist Approach. Meta: Translator's Journal 48 (4), 481-497. doi: 10.7202/008533ar

Risku, H. (1998). Translatorische Kompetenz. Kognitive Grundlagen des Übersetzens als Expertentätigkeit. Tübingen: Stauffenburg.

Robinson, D. (2003). Becoming a Translator. An Introduction to the Theory and Practice of Translation. London/New York: Routledge.

Shreve, G. (2006). The Translator's Handbook. Rockville: Schreiber Publishing.

Snell-Hornby, M. (1992). The Professional Translator of Tomorrow: Language Specialist or AllRound Expert? In: A. Loddegaard \& C. Dollerup (Eds.) Teaching Translation and Interpreting: Training, Talent, and Experience (pp. 9-22). Amsterdam/Philadelphia: John Benjamins.

Statista. (n.d.). Retrieved from https:/www.statista.com/topics/3137/cosmetics-industry/ (2020, June 24).

Stolze, R. (2015). Hermeneutische Übersetzungskompetenz. Grundlagen und Didaktik. Berlin: Frank \& Timme.

Whyatt, B. (2012). Translation as a Human Skill. From Predisposition to Expertise. Poznań: Wydawnictwo Naukowe UAM.

Wills, W. (1976). Perspectives and Limitations of a Didactic Framework for the Teaching of Translation. In: R. W. Brislin (Ed.) Translation. Applications and Research (pp. 117-137). New York: Gardner Press.

Wills, W. (1982). The Science of Translation. Problems and Methods. Tübingen: Gunter Narr.

Wills, W. (1996). Knowledge and Skills in Translator Behavior. Amsterdam/Philadelphia: John Benjamins. 